\title{
PREVALENCE OF UNINTENDED PREGNANCY AND ASSOCIATED FACTORS IN PORT-SAID CITY
}

\author{
Prof. Dr. Sanaa Aly Nor, Assistant prof. Hedayat Abel - raoof Amasha, Assistant \\ prof. Nagat Salah Salama, Shymaa Abdel- rahman Osman Abdel-haleem. \\ Prof of Obstetric and Gynecology, Faculty of Nursing-Zgazig University, Assistant \\ Prof of Maternity, Obstetric and Gynecological Nursing, Faculty of Nursing - Port- \\ said University, Assistant Prof of Maternity, Obstetric and Gynecological Nursing, \\ Faculty of Nursing - Port-said University
}

\begin{abstract}
Background: Unintended pregnancy is a key public health indicator. Estimating the prevalence of unintended pregnancy and identifying risk factors are crucial to the design of effective preventive interventions.Aim: The study was aimed to explore the prevalence of unintended pregnancy and associated factors in port-said city.Subject and Methods: The study was carried out at ante-natal clinics in all maternal and child health settings representing the six districts of Port-said using a cross-sectional descriptive design. The study subjects consisted of 600 women who attended the previous mentioned settings. A structured interviewed schedule sheet designed and utilized to collect the necessary data about unintended pregnancy, contraceptives and factors influencing them.Results: Results of study showed that about one third of the studied women were exposed to unintended pregnancy. Regarding reasons given by women for UP, almost half of them didn't use contraceptives and partially similar proportion were exposed to failure of the method used for contraception, and the rest reported that they discontinued using contraceptive method before the current pregnancy. A statistically significant relation was visible in the present study between deprived socio-economic backgrounds and the rate of unintended pregnancy.

Conclusion: Near to one third of women were exposed to unintended pregnancy. Age, age at first marriage, educational status of women, economy of the household, children ever born, contraceptive use, and spousal communication were significantly associated with unintended pregnancy in Port said.Recommendations: Mass media should be used more effectively as a powerful way to disseminate consistent knowledge to large number of the population about unintended pregnancy and contraceptives. Raising women awareness about contraceptive is imperative. Particular attention should be given about ECPs in case of unprotected intercourse to prevent unwanted pregnancy.
\end{abstract}

Key words: Unintended Pregnancy $\bullet$ Prevalence • Associated factors. 


\section{INTRODUCTION}

Unintended pregnancy is an important public health issue in both high income and also in low and middle income countries because of its negative association with the social and health outcomes for both mothers and children (WHO, 2013). A key objective of global public health policy is the reduction of the number of unplanned conceptions. Available evidence shows that unplanned pregnancies can have a negative effect on women's lives and result in poorer outcomes than those that are planned (Gipson et al , 2008). Many pregnant women will need to end a pregnancy to avoid risks to their lives, psychological trauma, and socio economic turmoil (IPAS, 2004).

Estimating the prevalence of unplanned pregnancy and identifying risk factors are crucial to the design of effective preventive interventions. Yet attempts to do so have been beset by methodological challenges (Krause , 2012). A study was conducted in Egypt to estimate the prevalence and correlates of unintended pregnancy among evermarried women. The study revealed that near one fifth of women reported unintended pregnancy. The Egyptian rate of unintended pregnancy is closer to that found in the Islamic Republic of Iran, where the rate was 35\% (Shaheen et al , 2007). This prevalence does not reflect the true magnitude of the problem, but can rather be considered as an underestimate since it was only calculated among ever-married women, and those whose pregnancies ended in birth (Abbasi-Shavazi, 2004).

Unmet need for contraception can lead to unintended pregnancies, with their harmful consequences such as unsafe abortions and unwanted births (Population Action International Healthy , 2011). Despite the widely available family planning effort to reduce UP, Goto et al. (2002) study in Japan revealed that $46.2 \%$ of the pregnancies were unintended and more than two fifths of them had repeated experience of UP, the rate of is still significantly large. Incorrect or inconsistent use of contraceptive contributed to the greater proportion of UP especially in developed countries however, in developing world lack of access to contraceptive is the underlying reason (WHO, 2013).

Numerous studies have shown that unmet need for family planning can have significant consequences for the health and well-being of women and children (Seyfried, 2011). Family planning (FP) began to be viewed as a way of making changes in women's lives, securing women's empowerment and ensuring their well- 
being. Unmet need for FP is the number or percent of women currently married who are fecund and who desire to either terminate (or postpone childbearing, but who are no currently using a contraceptive method (Cleland, 2006). The decision to continue or discontinue use of a contraceptive involves a number of factors - the acceptability of contraceptive options, current and future circumstances, and fertility desires. Knowledge of the factors that may lead to contraceptive discontinuation remains incomplete, and a better understanding is hampered by the lack of a comprehensive framework that acknowledges the multiple and complex reasons that influence the decision to switch methods or stop using one altogether.

Bongaarts et al (2012) reported that many social determinants can influence the demand for and use of FP, either individually or in various combinations such as literacy status, spousal communication, religion, women's autonomy, age, total children ever born, age at first marriage, FP workers' visit and knowledge about FP are important to explain unintended pregnancy. In the multivariate analysis, these variables were found to have statistically significant influence on unintended pregnancy.

\section{Significance of the Study:}

In the literature review related to the factors associated with unintended pregnancy, it was observed that contraceptive failure was one of the most important factors. Contraceptive failure refers to incorrect or inconsistent use of a method or lack of use of any form of contraception. Despite the widely available family planning efforts to reduce unwanted pregnancy, the rate of unintended pregnancy is still significantly large. Incorrect or inconsistent use of contraceptive contribute to the greater proportion of unintended pregnancy especially in developed countries however, in developing world lack of access to contraceptive is the underlying reason (WHO, 2013). The main aims of this study are to find the associated factors, design and evaluate the efficiency of an evidence - based guideline on nurse's performance concerning family planning counseling to assist individuals and couples to space their children, prevent unintended pregnancies, and improve their overall reproductive health. 


\section{AIM OF STUDY:}

The aim of this study was to explore the prevalence of unintended pregnancy and associated factors in port-said city.

\section{SUBJECT AND METHODS:}

Research design: a cross sectional descriptive design was utilized for women to collect data about unintended pregnancy, contraceptives and factors influencing them. Study setting: to ensure generalization of the study results on Port Said City, the study was carried out at antenatal clinics in all maternal and child health settings representing the six districts of Port-said, namely : primary health care centers (Portfouad (1), Port-fouad (2), Bank elescan, El manakh (1), El manakh (2), El Kuwait, El $\operatorname{arab}(1)$, El arab(2), Fatma elzahraa, Omar Ebn Elkhatab, El abouty, Osman Ebn Afan, Mostafa kamel, and El gwhara) \& hospitals (EL ameri hospital (out patient), El nasr hospital (out patient), Port- fouad hospital (out patient), and El tadamon hospital(out patient)). Subjects: a purposive sample of 600 women who attended the study setting and fulfilling the inclusion criteria were enrolled in this study during study period ( 8 months). Inclusion criteria included women had at least have one child or more, no medical or obstetric disorders, and no contraindications for using FP methods.

\section{Tools for data collection:}

A structured interviewed schedule sheet for women, this tool was designed mainly to collect data related to: -

Socio-demographic data: which include; mothers name, age, address, education, family income, occupation, period of marriage, husband's age, husband's education , occupation, and housing condition.

Obstetrical history: which include gravidity, parity, number of abortion, number of living children, and pregnancy interval.

- History of current pregnancy: as pregnancy intention, feeling after unintended pregnancy, and abortion's attempt.

Determinants of unintended pregnancy, contraceptive use history, and sexual activity.

\section{Content Validity:}

After the tool had been designed, it was tested for its validity and reliability. Then the pilot study was carried out on $10 \%$ of the sample in the study setting that were 
excluded from the study sample. The purposes of the pilot study were to test the applicability and clarify the feasibility of the study tools and it served to estimate the time needed to complete the tools. It also helped to find out any obstacles and problems that might interfere with data collection, based on findings of the pilot study, certain modification of the tools were done. Subjects included in the pilot study were excluded from the study subjects. Following this pilot study, the process of data collection was performed.

\section{Methods of study}

- An official letter from the dean of the faculty of nursing was sent to the director of the selected area of the study. The director of each clinic was contacted and informed in order to obtain permission to include women on the present research.

- The tools used in data collection. The tools were reviewed by a jury of 10 experts in the field of obstetrics and gynecological nursing and medicine to ascertain their content validity.

- Informed consent was obtained from each woman in the study after explaining its purpose and importance. Confidentially of the information was assured by the researcher.

- A pilot study was carried out over a period of two months. It was conducted on $10 \%$ of total sample size involving women to evaluate the content validity, time required to fill each tool and feasibility of tools of the study. Necessary modifications were carried out as revealed from the pilot study.

\section{Statistical analysis of data:}

Up completion of data collection, variables included in the structured interview sheet, were coded prior to computerized data entry. The raw data were coded and transformed into coding sheets. The results were checked. Then, the data were entered using SPSS 20.0 statistical software package. Output drafts were checked against the revised coded data for typing and spelling mistakes. Finally, analysis and interpretation of data were conducted. 


\section{RESULTS :}

Table (1): illustrates the socio-demographic characteristics of the studied pregnant women. The table reveals that the ages of women ranged from 23 - 40 years; with a

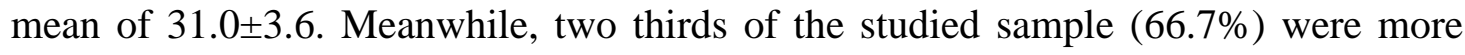
than 30 years. Almost all of them (99.7\%) were married and $89.8 \%$ had urban residence and $23.5 \%$ reported that they were employed at the time of the study. The same table denotes that more than two thirds of the studied women $(67.2 \%)$ had secondary level of education and $20.2 \%$ could just read and write or had primary education. Meanwhile, more than one half $(63.2 \%)$ reported that their monthly family income was not enough and their mean crowding index was $2.3 \pm 0.3$.

Table (2): reveals that the ages of husbands ranged between 26-45years; with a mean of $35.9 \pm 3.8$. Almost three quarters of the husbands $(73.0 \%)$ had secondary level of education. Meanwhile, $20.0 \%$ of them could just read and write or had primary education. As for husband's job status, only $3.2 \%$ were not employed at the time of study .

Figure (1): shows the distribution of the studied women according to their intention of pregnancy. The figure shows that about one third of the studied women $(31.3 \%)$ were exposed to unintended pregnancy. .

As shown in table: (3), women with unintended pregnancy were more likely to be older $(30-\leq 40)$ and married at an age more than 20 compared to those who had intended pregnancy $(77.7 \%$ vs. $61.7 \%$ and $88.8 \%$ vs. $74.8 \%$ respectively), differences observed are statistically significant $\left({ }^{\mathrm{FE}} \mathrm{P}=0.03 *\right)$. Meanwhile, they significantly more apt to be housewives, had low level of education, and insufficient income $(88.8 \%$ vs. $70.9 \%, 38.9 \%$ vs. $11.6 \%$ and $83.5 \%$ vs. $53.9 \%$ respectively).

Table (4): reveals that husbands of the unintended pregnant women were more likely to be in the middle age groups $(30-<40)$, had low level of education and unemployed (83.0\% vs.76.2\%, 36.7\% vs.12.3\% and $5.3 \%$ vs. $2.2 \%$ respectively). Differences observed are statistically significant $(\mathrm{P}<0.0001 *)$.

As shown in table (5): unintended pregnant women were more likely to use contraceptive pills, for short period (less than one year), and with improper counseling 
compared to those with intended pregnancy $(41.9 \%$ vs. $20.9 \%, 52.4 \%$ vs. $14.0 \%$ and $49.5 \%$ vs. $4.9 \%$ respectively).Meanwhile, they faced more side effects than the control group (54.3\% vs.12.9\%). Differences observed are statistically significant $\mathrm{P}<0.0001$ *.

Table (1): Socio-demographic characteristics of the studied pregnant women $(n=600)$

\begin{tabular}{|c|c|c|}
\hline \multirow[t]{2}{*}{ Socio-demographic characteristics } & \multicolumn{2}{|c|}{$\begin{array}{l}\text { Studied pregnant women } \\
(n=600)\end{array}$} \\
\hline & No. & $\%$ \\
\hline $\begin{array}{l}\text { Age (years) } \\
20- \\
30-\leq 40\end{array}$ & $\begin{array}{l}200 \\
400\end{array}$ & $\begin{array}{l}33.3 \\
66.7\end{array}$ \\
\hline $\begin{array}{l}\text { Min-Max } \\
\text { Mean } \pm \text { SD }\end{array}$ & \multicolumn{2}{|c|}{$\begin{array}{l}23.0-40.0 \\
31.0 \pm 3.6\end{array}$} \\
\hline $\begin{array}{l}\text { Age at marriage } \\
<20 \\
\geq 20\end{array}$ & $\begin{array}{l}125 \\
475\end{array}$ & $\begin{array}{l}20.8 \\
79.2\end{array}$ \\
\hline $\begin{array}{l}\text { Min-Max } \\
\text { Mean } \pm \text { SD }\end{array}$ & \multicolumn{2}{|c|}{$\begin{array}{l}17.0-30.0 \\
21.7 \pm 2.6\end{array}$} \\
\hline $\begin{array}{l}\text { Period of marriage } \\
<10 \\
\geq 10\end{array}$ & $\begin{array}{l}311 \\
289\end{array}$ & $\begin{array}{l}51.8 \\
48.2\end{array}$ \\
\hline $\begin{array}{l}\text { Min-Max } \\
\text { Mean } \pm \text { SD }\end{array}$ & \multicolumn{2}{|c|}{$\begin{array}{l}3.0-18.0 \\
9.2 \pm 2.9\end{array}$} \\
\hline $\begin{array}{l}\text { Marital status } \\
\text { Married } \\
\text { Divorced }\end{array}$ & $\begin{array}{c}598 \\
2\end{array}$ & $\begin{array}{c}99.7 \\
0.3\end{array}$ \\
\hline $\begin{array}{l}\text { Residence } \\
\text { Urban } \\
\text { Rural }\end{array}$ & $\begin{array}{c}539 \\
61 \\
\end{array}$ & $\begin{array}{l}89.8 \\
10.2\end{array}$ \\
\hline $\begin{array}{l}\text { Occupation } \\
\text { Housewife } \\
\text { Working } \\
\end{array}$ & $\begin{array}{l}459 \\
141\end{array}$ & $\begin{array}{l}76.5 \\
23.5\end{array}$ \\
\hline $\begin{array}{l}\text { Level of education } \\
\text { can read and write } \\
\text { primary education } \\
\text { Secondary education } \\
\text { University education }\end{array}$ & $\begin{array}{c}9 \\
112 \\
403 \\
76\end{array}$ & $\begin{array}{l}1.5 \\
18.7 \\
67.2 \\
12.7\end{array}$ \\
\hline $\begin{array}{l}\text { Monthly family income } \\
\text { Enough } \\
\text { Not enough }\end{array}$ & $\begin{array}{l}221 \\
379 \\
\end{array}$ & $\begin{array}{l}36.8 \\
63.2\end{array}$ \\
\hline $\begin{array}{l}\text { Crowding index } \\
\text { Min-Max } \\
\text { Mean } \pm \text { SD }\end{array}$ & \multicolumn{2}{|c|}{$\begin{array}{l}1.3-3.0 \\
2.3 \pm 0.3\end{array}$} \\
\hline
\end{tabular}


Table (2): Socio-demographic characteristics of the studied pregnant women's husbands

$$
(\mathrm{n}=600)
$$

\begin{tabular}{|c|c|c|}
\hline \multirow[t]{2}{*}{ Socio-demographic characteristics of husbands } & \multicolumn{2}{|c|}{$\begin{array}{l}\text { Studied pregnant women } \\
(n=600)\end{array}$} \\
\hline & No. & $\%$ \\
\hline \multicolumn{3}{|l|}{ Age (vears) } \\
\hline $20-$ & 22 & 3.7 \\
\hline 30- & 470 & 78.3 \\
\hline $40-<50$ & 108 & 18.0 \\
\hline Min-Max & \multirow{2}{*}{\multicolumn{2}{|c|}{$\begin{array}{l}26.0-45.0 \\
35.9 \pm 3.8\end{array}$}} \\
\hline Mean \pm SD & & \\
\hline \multicolumn{3}{|l|}{ Level of education } \\
\hline Read and write & 37 & 6.2 \\
\hline primary education & 83 & 13.8 \\
\hline Secondary education & 438 & 73.0 \\
\hline University education & 42 & 7.0 \\
\hline \multicolumn{3}{|l|}{ Occupation } \\
\hline Work & 581 & 96.8 \\
\hline Not work & 19 & 3.2 \\
\hline
\end{tabular}

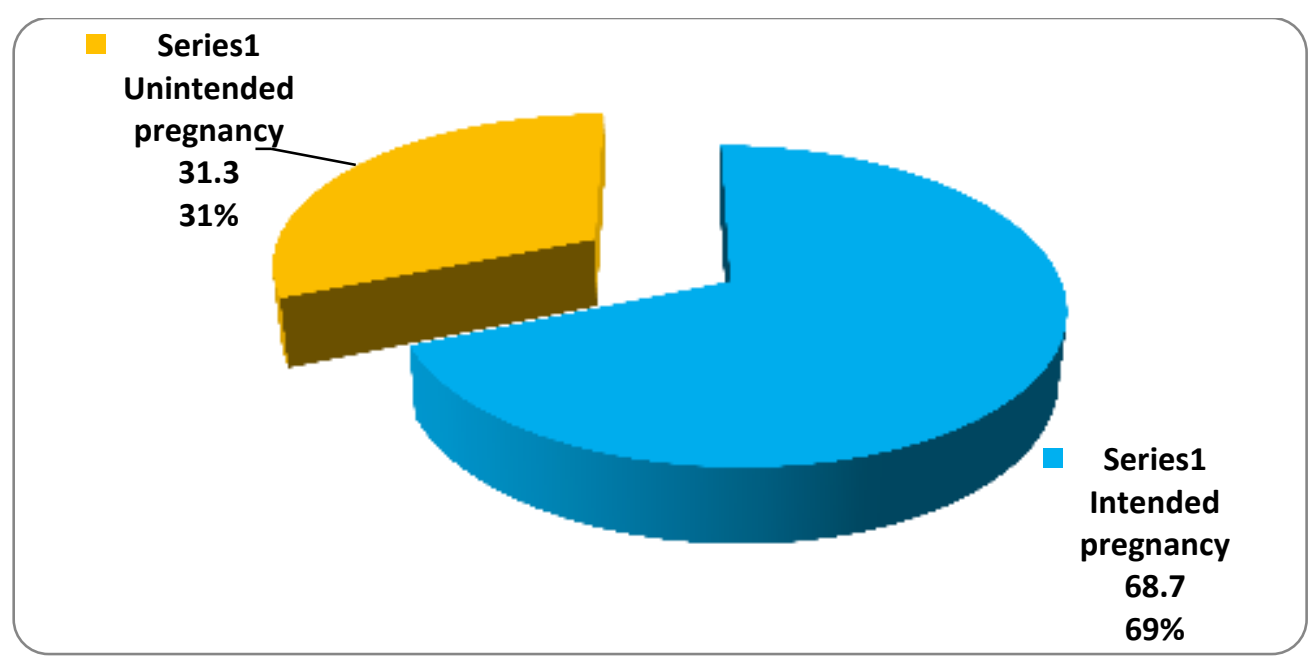

Figure (1): Distribution of the studied women according to their intention of

$$
\text { pregnancy }(\mathrm{n}=600)
$$


Table (3): Relation between the intention of the current pregnancy and sociodemographic characteristics of the studied pregnant women $(n=600)$

\begin{tabular}{|c|c|c|c|c|c|}
\hline \multirow{3}{*}{$\begin{array}{l}\text { Socio-demographic } \\
\text { characteristics }\end{array}$} & \multicolumn{4}{|c|}{ Groups } & \multirow{3}{*}{ Significance } \\
\hline & \multicolumn{2}{|c|}{$\begin{array}{c}\text { Unintended } \\
(\mathrm{n}=188)\end{array}$} & \multicolumn{2}{|c|}{$\begin{array}{c}\text { Intended } \\
(\mathrm{n}=\mathbf{4 1 2})\end{array}$} & \\
\hline & No. & $\%$ & No. & $\%$ & \\
\hline $\begin{array}{l}\text { Age (years) } \\
20- \\
30-\leq 40\end{array}$ & $\begin{array}{l}42 \\
146\end{array}$ & $\begin{array}{l}22.3 \\
77.7\end{array}$ & $\begin{array}{l}158 \\
254\end{array}$ & $\begin{array}{l}38.3 \\
61.7\end{array}$ & $\begin{array}{c}\mathrm{X}^{2}=14.888 \\
\mathrm{P}<0.00001 *\end{array}$ \\
\hline $\begin{array}{l}\text { Age at marriage } \\
\text { Less than } 20 \\
\text { More than } 20\end{array}$ & $\begin{array}{c}21 \\
167\end{array}$ & $\begin{array}{l}11.2 \\
88.8\end{array}$ & $\begin{array}{l}104 \\
308\end{array}$ & $\begin{array}{l}25.2 \\
74.8\end{array}$ & $\begin{array}{l}\mathrm{X}^{2}=15.50 \\
\mathrm{P}<0.0001 *\end{array}$ \\
\hline $\begin{array}{l}\text { Period of marriage } \\
\text { Less than } 10 \\
\text { More than } 10\end{array}$ & $\begin{array}{l}94 \\
94\end{array}$ & $\begin{array}{l}50.0 \\
50.0\end{array}$ & $\begin{array}{l}217 \\
195\end{array}$ & $\begin{array}{l}52.7 \\
47.3\end{array}$ & $\begin{array}{l}X^{2}=0.369 \\
P=0.544\end{array}$ \\
\hline $\begin{array}{l}\text { Residence } \\
\text { Urban } \\
\text { Rural }\end{array}$ & $\begin{array}{c}164 \\
24\end{array}$ & $\begin{array}{l}87.2 \\
12.8\end{array}$ & $\begin{array}{c}375 \\
37\end{array}$ & $\begin{array}{c}91.0 \\
9.0\end{array}$ & $\begin{aligned} X^{2} & =2.025 \\
P & =0.155\end{aligned}$ \\
\hline $\begin{array}{l}\text { Marital status } \\
\text { Married } \\
\text { Divorced }\end{array}$ & $\begin{array}{c}186 \\
2\end{array}$ & $\begin{array}{c}98.9 \\
1.1\end{array}$ & $\begin{array}{c}412 \\
0\end{array}$ & $\begin{array}{c}100.0 \\
0.0\end{array}$ & ${ }^{\mathrm{FE}} \mathrm{P}=0.03 *$ \\
\hline $\begin{array}{l}\text { Occupation } \\
\text { Housewife } \\
\text { Working } \\
\end{array}$ & $\begin{array}{c}167 \\
21\end{array}$ & $\begin{array}{l}88.8 \\
11.2\end{array}$ & $\begin{array}{l}292 \\
120\end{array}$ & $\begin{array}{l}70.9 \\
29.1\end{array}$ & $\begin{array}{l}\mathrm{X}^{2}=23.152 \\
\mathrm{P}<0.0001 *\end{array}$ \\
\hline $\begin{array}{l}\text { Level of education } \\
\text { can read and write } \\
\text { primary education } \\
\text { Secondary education } \\
\text { University education }\end{array}$ & $\begin{array}{c}8 \\
65 \\
111 \\
4\end{array}$ & $\begin{array}{c}4.3 \\
34.6 \\
59.0 \\
2.1\end{array}$ & $\begin{array}{c}1 \\
47 \\
292 \\
72\end{array}$ & $\begin{array}{c}0.2 \\
11.4 \\
70.9 \\
17.5\end{array}$ & $\begin{aligned} \mathrm{X}^{2} & =77.671 \\
{ }_{\mathrm{MC}} \mathrm{P} & =0.0001 *\end{aligned}$ \\
\hline $\begin{array}{l}\text { Crowding index } \\
\text { Min-Max } \\
\text { Mean } \pm \text { SD }\end{array}$ & \multicolumn{2}{|c|}{$\begin{array}{l}1.7-3.0 \\
2.4 \pm 0.3\end{array}$} & \multicolumn{2}{|c|}{$\begin{array}{l}1.3-3.0 \\
2.2 \pm 0.3\end{array}$} & $\begin{array}{c}\mathrm{Z}=5.340 \\
\mathrm{P}<0.0001 *\end{array}$ \\
\hline $\begin{array}{l}\text { Monthly family income } \\
\text { Enough } \\
\text { Not enough }\end{array}$ & $\begin{array}{c}31 \\
157\end{array}$ & $\begin{array}{l}16.5 \\
83.5\end{array}$ & $\begin{array}{l}190 \\
222\end{array}$ & $\begin{array}{l}46.1 \\
53.9\end{array}$ & $\begin{array}{l}\mathrm{X}^{2}=48.703 \\
\mathrm{P}<0.0001^{*}\end{array}$ \\
\hline
\end{tabular}

$\mathbf{X}^{2}$ : Chi-Square test ${ }^{\text {MCC }} \mathbf{P}$ : Monte Carlo corrected P-value ${ }^{\text {FE }} \mathbf{P}$ : Fisher's Exact test

Z: Mann Whitney test *significant at $\mathbf{P} \leq \mathbf{0 . 0 5}$ 
Table (4): Relation between the intention of the current pregnancy and sociodemographic characteristics of the studied pregnant women's husbands $(n=600)$

\begin{tabular}{|c|c|c|c|c|c|}
\hline \multirow{3}{*}{$\begin{array}{c}\text { Socio-demographic } \\
\text { characteristics of husbands }\end{array}$} & \multicolumn{4}{|c|}{ Groups } & \multirow{3}{*}{ Significance } \\
\hline & \multicolumn{2}{|c|}{$\begin{array}{l}\text { Unintended } \\
(n=188)\end{array}$} & \multicolumn{2}{|c|}{$\begin{array}{c}\text { Intended } \\
(n=412)\end{array}$} & \\
\hline & No. & $\%$ & No. & $\%$ & \\
\hline Age (years) & & & & & \\
\hline $20-$ & 5 & 2.7 & 17 & 4.1 & $X^{2}=3.525$ \\
\hline $30-$ & 156 & 83.0 & 314 & 76.2 & $\mathrm{P}=0.178$ \\
\hline $40-<50$ & 27 & 14.3 & 81 & 19.7 & \\
\hline Level of education & & & & & \\
\hline can read and write & 20 & 10.6 & 17 & 4.1 & $y^{2}-50774$ \\
\hline primary education & 49 & 26.1 & 34 & 8.2 & $\begin{array}{l}X=58 . / 14 \\
P<00001 *\end{array}$ \\
\hline Secondary education & 118 & 62.8 & 320 & 77.7 & \\
\hline University education & 1 & 0.5 & 41 & 10.0 & \\
\hline Occupation & & & & & \\
\hline Work & 178 & 94.7 & 403 & 97.8 & $X^{2}=4.137$ \\
\hline Not work & 10 & 5.3 & 9 & 2.2 & $\mathrm{P}=0.042 *$ \\
\hline
\end{tabular}

$X^{2}$ : Chi-Square test $\quad$ *significant at $P \leq 0.05$

Table (5): Relation between intention of the current pregnancy and use of contraceptives before recent pregnancy $(n=600)$

\begin{tabular}{|c|c|c|c|c|c|}
\hline \multirow{3}{*}{ Family planning methods used } & \multicolumn{4}{|c|}{ Groups } & \multirow{3}{*}{ Significance } \\
\hline & \multicolumn{2}{|c|}{$\begin{array}{c}\text { Unintended } \\
(\mathrm{n}=105)\end{array}$} & \multicolumn{2}{|c|}{$\begin{array}{c}\text { intended } \\
(n=364)\end{array}$} & \\
\hline & No. & $\%$ & No. & $\%$ & \\
\hline Type of family planning used & & & & & \multirow{7}{*}{$\begin{array}{l}Z=2.036 \\
P=0.042^{*}\end{array}$} \\
\hline Condoms & 8 & 7.6 & 16 & 4.4 & \\
\hline Pills (combined or progesterone only ) & 44 & 41.9 & 76 & 20.9 & \\
\hline Hormonal injection & 2 & 1.9 & 74 & 20.3 & \\
\hline IUD & 35 & 33.3 & 184 & 50.5 & \\
\hline Period safety & 2 & 1.9 & 5 & 1.4 & \\
\hline Lactational amenorrhea & 14 & 13.3 & 9 & 2.5 & \\
\hline \multicolumn{5}{|l|}{ Use based on counseling } & \multirow{3}{*}{$\begin{array}{l}X 2=57.594 \\
P<0.0001^{*}\end{array}$} \\
\hline Yes & 53 & 50.5 & 346 & 95.1 & \\
\hline Not & 52 & 49.5 & 18 & 4.9 & \\
\hline \multicolumn{5}{|l|}{ Duration of use } & \multirow{4}{*}{$\begin{array}{c}\mathrm{t}=2.167 \\
\mathrm{P}=0.037 *\end{array}$} \\
\hline One month & 2 & 1.9 & 1 & 0.3 & \\
\hline Less than a year & 55 & 52.4 & 51 & 14.0 & \\
\hline More than a year & 48 & 45.7 & 312 & 85.7 & \\
\hline \multicolumn{5}{|l|}{ Decision to use } & \multirow{4}{*}{$\begin{array}{c}Z=6.856 \\
P<0.0001^{*}\end{array}$} \\
\hline Husband only & 2 & 1.9 & 14 & 3.8 & \\
\hline Wife only & 76 & 72.4 & 111 & 30.5 & \\
\hline A joint decision between the spouse & 27 & 25.7 & 239 & 65.7 & \\
\hline
\end{tabular}




\begin{tabular}{|c|c|c|c|c|c|}
\hline $\begin{array}{l}\text { Occurrence of side effects after use the } \\
\text { method } \\
\text { Yes } \\
\text { No }\end{array}$ & $\begin{array}{l}57 \\
48\end{array}$ & $\begin{array}{l}54.3 \\
45.7\end{array}$ & $\begin{array}{c}47 \\
317\end{array}$ & $\begin{array}{l}12.9 \\
87.1\end{array}$ & ${ }^{\mathrm{MC}} \mathrm{P}=0.001 *$ \\
\hline \#Side effects & \multicolumn{2}{|c|}{$(n=57)$} & \multicolumn{2}{|c|}{$(n=47)$} & \\
\hline Bleeding between period & 34 & 50.0 & 24 & 51.1 & \\
\hline Increase in weight & 10 & 14.7 & 16 & 34.0 & \\
\hline Nausea & 4 & 5.9 & 0 & 0.0 & $\mathbf{F E}_{\mathrm{P}-0}-024 *$ \\
\hline Chest pain & 7 & 10.3 & 4 & 8.5 & \\
\hline Headache & 3 & 4.4 & 3 & 6.4 & \\
\hline Mood swings & 5 & 7.4 & 0 & 0.0 & \\
\hline Severe pelvic pain & 5 & 7.4 & 3 & 6.4 & \\
\hline
\end{tabular}

Z: Mann Whitney test X2:Chi-Square test ${ }^{\mathrm{MC}} \mathrm{P}$ : Monte Carlo test ${ }^{\mathrm{FE}} \mathrm{P}$ : Fisher's Exact test t: ttest *significant at $\mathrm{P} \leq \mathbf{0 . 0 5}$

\# Categories are not mutually exclusive

\section{DISCUSSION:}

Births that were unintended by the mother are at elevated risk of adverse social, economic, and health outcomes for the mother and the child. In less developed regions, about one-fourth of pregnancies are unintended (unwanted or mistimed) and 18 million undergo unsafe abortions each year, contributing to high rates of maternal death (Haub and Herstad, 2002). According to the present study findings, about one third of the studied women were exposed to unintended pregnancy. This is in coherence with $\boldsymbol{E l}$ zanaty et al (1995) in Egypt, and Johnson et al (2004) in Jordon ,Shaheen et al. (2007) in Islamic Republic of Iran and Hamadela and Tizta (2012) in Ethiopia, where the rate was 35.0\%. Unlikely, a lower proportion "one fifth of all the births" were reported by Jaeni et al (2009) in Indonesia, Faye et al (2013)in Senegal "14.3\%"and Sedgh et al. (2014) in Nigeria "28.0\%". Moreover, a higher proportion of women experiencing unintended pregnancy was reported by nearly half of women Goto et al (2002) in Japan, Adhikari et al (2009) in Nepal and $54.1 \%$ in Tanzania (Exavery et al.,2014). Additionally, most of the research on the prevalence of unintended pregnancies is based on data from the United States. Studies report that the prevalence of unintended pregnancies ranges from one third upwards to one half of all births (Finer and Zolna, 2014). The discrepancies among the various studies addressing the above mentioned prevalence and the present one has been attributed to diverse tradition, cultural and religious denominations between various countries. 
The present finding investigates the factors influencing the occurrence of unintended pregnancy. These include socioeconomic, socio-cultural, demographic and access to health information/services. The bivariate analysis showed that the variables such as literacy status, spousal communication, religion, women's autonomy, age, total children ever born, age at first marriage, FP workers' visit and knowledge about FP are important to explain unintended pregnancy. In the multivariate analysis, these variables were found to have statistically significant influence on unintended pregnancy. These finding are partially in congruence with Bongaarts et al (2012). They reported that many social determinants can influence the demand for and use of $\mathrm{FP}$, either individually or in various combinations.

A number of studies have shown that a relationship exist between age of the woman and increased risk of unintended pregnancy. The results of this study shows that women with unintended pregnancy were more likely to be older $(30-\leq 40)$. This is partially in agreement with Adhikari et al (2009)from Nepal, Jaeni et al (2009) study from Indonesia, Najafian, et al (2010) from Iran and Geda and Lako (2012) from Nigeria. These findings matched with those of studies conducted in Ecuador, Vietnam, China, and Bangladesh among married pregnant women, who were in reproductive age group, showed that as women's age advances, the likelihood of unintended pregnancy increases (Calverton, 2014). Conversely, Sriprasert et al (2014) study in United States indicated that women less than 20 years of age at the time of their pregnancy were more likely to experience their pregnancy as unintended, compared to those who were over 40 years of age.

The present study shows that women with unintended pregnancy married at an age more than 20 compared to those who had intended pregnancy. This is due to the delayed age of marriage in Egypt. Similarly, Kost and Forrest (1988) study in USA reported that women married at an age of 35 years and more were more likely to experience an unintended pregnancy. Unlikely, Nasab et al (2010) in Iran found that women married before the age of 18 were 4.6 times more likely to experience unintended pregnancy compared to those who married at age of 18 and above. Also Nasab et al (2010) study found that the rate of unintended pregnancy significantly increase in the age group less than 18 as compared to those married between 19-24 years. Additionally, Goto et al (2002) in Japan found that there is significant negative 
relationship between age at first marriage and unintended pregnancy which could be related to the earlier initiation of sexual intercourse which exposes women to becoming pregnant several times.

Regarding to literacy status, the finding of the present study shows that almost half of the unintended pregnant women had low level of education. This is supported by Finer and Zolna (2014) study in United States who found that women without a high school degree had the highest unintended pregnancy rate among all educational levels (73 per 1,000 women aged 15-44), and rates were lower for women with more years of education. Meanwhile, Crosby et al (2003) study revealed that women with less education were more likely to experience unintended pregnancy. In contrast, the study of Abbasi-Shavazi (2004) \& Stephenson et al (2008) noticed that women with primary, secondary and higher education were more likely to report unintended pregnancy compared to un-educated women whereas those women whom partner has higher education were less likely to report unintended pregnancy. Moreover, Goto et al (2002) in Kenya, Japan and Nepal reported that there was no significant association between the experience of unintended pregnancy and women's education.

Such dissimilarities among the results of the above-mentioned studies and the present one could be attributed to the difference in the sample size and its criteria of selection. Moreover, the state of being well did not mainly depend on the educational level, but mostly on woman attitude toward seeking healthy and preventive behavior. In this regard, the maternity nurse should recognize that health education leads to a better-combined input that increases the person's ability and willingness to change preventive health behaviors.

More than three quarters of the unintended pregnant women in this study were housewives and had an insufficient income. This is partially in accordance with Finer and Zolna (2014) who reported that the rate of unintended pregnancy among higherincome women was less than half the national rate (18 vs. 45 per 1,000), while it was 112 per 1,000 women aged 15-44 in 2011among poor women. This is possibly explained by the fact that women in formal employment tend to earn more, have higher levels of reproductive health knowledge and participate in social networks that support family planning and reduced fertility. Conversely, Abbasi-Shavazi (2004) in Iran and Exavery et al (2014) in Tanzania found that women occupation was not 
significantly related with unintended pregnancy. This dissimilarity between the various studies may be related to the difference in the setting or the difference in the measurement of the socioeconomic variable. Most of the studies calculate this variable after analyzing the proxy variables of socioeconomic status, and few studies measure this variable by asking the income of the household categories of this variable (poor, middle and rich) arbitrary; therefore, the results need to be interpreted cautiously (Exavery, et al.,2014\&Mukaba et al.,2015).

The place of residence has mixed effects on unintended pregnancy. Some studies found that women from urban areas are at higher risk of unintended pregnancy, while others found that women from rural area are more at risk of unintended pregnancy. Similarly the present study finds no significant relation between the residence and unintended pregnancy. Braun et al., (2013) explained this by women preferences for contraceptive use in rural or urban areas that predict the risk of unintended pregnancy.

A statistically significant relation was visible in the present study between deprived socio-economic backgrounds and the rate of unintended pregnancy. This is matching with Bongaarts et al., (2012) in United States who showed that husband level of education is an important predictor of unintended pregnancy. Increasing level of education will help in improving the husband's awareness regarding the effective use of contraceptives which in turn helps his wife in the choice of contraceptives.

Unintended pregnant women were more likely to use contraceptive pills before the current pregnancy, for a short period (less than one year), and with improper counseling compared to those with intended pregnancy. Meanwhile, they faced more side effects than the control group. This is also corroborated with Geda and Lako, (2011) who mentioned that mother visited by family planning worker before pregnancy were less likely to experience unintended pregnancy as compared to not visited. The possible reason may be family planning outreach workers provide information and service and mobilize the community on family planning matter. They increase women knowledge about contraceptives, counsel them about various options available and how to cope with side effects and the consequences of unintended pregnancy

The present result revealed that less than one third of unintended pregnant women used contraceptives based on a joint decision between spouses before recent 
pregnancy. This is in agreement with Kaye (2006) \& Nwokocha (2006) who reported that current use of family planning methods based on a joint decision is very low among Uganda women. They explained this by the fact that in patriarchal society; women are often given less opportunity to be self-supportive.

\section{CONCLUSION:}

Based on study findings, it can be concluded that:

Near to one third of women were exposed to unintended pregnancy. Age, age at first marriage, educational status of women, economy of the household, children ever born, contraceptive use, and spousal communication were significantly associated with unintended pregnancy in Port said. Overall, there is a substantial demand among women for effective contraceptive methods. This can be done by focusing on information and education to the newly wed couples and pregnant mothers during antenatal check-ups.

\section{RECOMMENDATIONS:}

Based on the results of the present study, the following recommendations were suggested:

Mass media should be used more effectively as a powerful way to disseminate consistent knowledge to large number of the population about unintended pregnancy and contraceptives. Husband involvement in family planning, particularly in areas with deep-rooted patriarchal culture is recommended. Raising women awareness about contraceptive is imperative. Particular attention should be given about ECPs in case of unprotected intercourse to prevent unwanted pregnancy. Simple illustrative booklets and pamphlets in Arabic language should be prepared and made available in family planning centers addressing practical issues related to the unintended pregnancy and contraceptives to reduce the unmet need with particular attention in the country. Replication of the present study at different setting and among various subjects is recommended. Meanwhile, further research is recommended about other pre determinants of unintended pregnancy and its consequences on both mother and baby. 


\section{REFERENCES:}

Abbasi-Shavazi MJ, Hosseini-chavoshi M, Aghajanian A, Delavar B, Mehyar A (2004): Unintended pregnancies in the Islamic Republic of Iran: Level and Correlates. Asia-Pacific Population Journal, 19(1):27-38.

Adhikari, R., Soonthorndhada, K. \& Prasartkul, P( 2009): "Correlates of unintended pregnancy among currently pregnant married women in Nepal", BMC International Health and Human Rights, vol. 9, no. 1, pp. 17.

Bongaarts, J., J. Cleland, J.W. Townsend, J.T. Bertrand, and M.D. Gupta.(2012): Family Planning Programs for the 21st Century. Rationale and Design. New York: The Population Council, Inc.

Braun R, Catalani C, Wimbush J, Israelski D (2013): Community health workers and mobile technology: a systematic review of the literature. PLoS One; 8(6):e65772.

Calverton MU(2014): Demographic and health survey. National institute of population studies islamabad, pakistan 2012-2013. Calverton: Macro International Inc .

Crosby, R.A., Di Clemente, R.J., Wingood, G.M., Rose, E. \& Lang, D. 2003:"Correlates of unplanned and unwanted pregnancy among African-American female teens.", American Journal of Preventive Medicine, vol. 25, no. 3, pp. 255-258.

El-Zanaty F, Way A. (2001): (Egypt demographic and health survey 2000. Calverton, Maryland [USA], Ministry of Health and Population [Egypt], National Population Council and ORC Macro.

Exavery A, Kante AM, Njozi M, Tani K, Doctor HV, Hingora A, et al.(2014): Predictors of mistimed, and unwanted pregnancies among women of childbearing age in Rufiji, Kilombero, and Ulanga districts of Tanzania. Reprod Health. 2014;11:63.

Faye CM, et al.(2013): Unintended pregnancy: magnitude and correlates in six urban sites in Senegal. Reproductive health; 59:10.1. 
Geda NR, Lako TK. A(2011): Population based study on Unintended Pregnancy among Married Women in a District in Southern Ethiopia. Journal of Geography and Regional Planning ;4(7):417-27.

Finer LB, Zolna MR(2014): Shifts in intended and unintended pregnancies in the United States, 2001-2008. Am J Public Health. 2014;104 Suppl 1:43-8

Gessessew, A. (2010): "Abortion and unwanted pregnancy in Adigrat Zonal Hospital, Tigray, North Ethiopia.", African Journal of Reproductive Health, vol. 14, no. 3, pp. 183- 188.

Gipson JD, Koenig MA, Hindin MJ.(2008): The eff ects of unintended pregnancy on infant, child, and parental health: a review of the literature. Stud Fam Plann; 39: 1838.

Goto, A., Yasumura, S., Reich, M.R. \&Fukao, A.( 2002): "Factors associated with unintended pregnancy in Yamagata, Japan.", Social science \& medicine, vol. 54, no. 7, pp. 1065-1079.

Hamadela B, Tizta T(2012): Unwanted pregnancy and associated factors among pregnant married women in Hosanna Town, Southern Ethiopia. PLoS One;7.6:e39074. doi: 10.1371/journal.pone.0039074.

Haub C, Herstad B.( 2002): Family planning worldwide , data sheet. Washington, DC, USA: Population Reference Bureau. Available at: http://www.prb.org/pdf/fam plan world wide_Eng.pdf. [Accessed 15 July 2013].

IPAS (2004): Maternal and Child Health, Adolescent, Unwanted Pregnancy and Abortion. Policies, Counseling and Clinical Care. Chapel Hill, NC, IPAS.Journal, 112. doi: 10.1007/s10995-010-0646-z.

Jaeni N, McDonald P, Utomo ID(2009): Determinants of Unintended Pregnancy among Ever-Married Women in Indonesia: An Analysis of the 2007 IDHS. Australian Demographic and Social Research Institute. 
Johnson, Kiersten, Osama al Zoubi, and Martin Wulfe (2004): Mistimed and Unwanted Pregnancies in Jordan. Calverton, Maryland, USA: Jordan Department of Statistics and ORC Macro.

Kaye DK(2006): Community perceptions and experiences of domestic violence and induced abortion in Wakiso District, Uganda, Qualitative Health Research, 16(8):1120-1128.

Kost K, Forrest JD. Intention status of U.S. births in (1988): Differences by mothers' socioeconomic and demographic characteristics. Fam Plan Perspect. 1995;27(1):11-7.

Krause EL.(2012): "They just happened": the curious case of the unplanned baby, Italian low fertility, and the "end" of rationality. Med Anthropol $Q$

2012; 26: 361-82.

Mukaba T, et al (2015): Family planning policy environment in the democratic republic of the Congo: levers of positive change and prospects for sustainability. Global Health: Science and Practice ;3(2):163-173.

Najafian M., Karami K. B., Cheraghi M., andJafari. R M. (2010): Prevalence of and Some Factors Relating with Unwanted Pregnancy, in Ahwaz City,Iran,. ISRN Obstetrics and Gynecology, vol. 2011,Article ID 523430;1- 4.

Nasab HS, Tavakoli R, Tavakoli H, Jahan HR, Shkravi FA.(2010): Unwanted Pregnancy and Factors Influencing it in Pregnant Mothers Referring to Semnan's Health Centers. World Applied Sciences Journal ;9(2):199-203.

Nwokocha, E.E. (2006): "Pregnancy Outcomes Among The Ibani Of Rivers State, Nigeria: Findings From Case-Studies” African Population Studies 21(1):93-118.

Population Action International Healthy(PAI)(2011): Why Population Matter to Maternal Health. Washington: Population Action International Healthy Family Healthy Planet.

Sedgh G, Singh S, Hussain R.( 2014): Intended and unintended pregnancies worldwide in 2012 and recent trends. Studies in Family Planning ;45(3):301-314. doi: 10.1111/j.1728-4465.2014.00393.x. 
Seyfried L., (2011): Family Planning and Maternal Health, The Effect of Family Planning and Maternal Health in the Democratic Republic of Congo, published master thesis, Faculty of Georgetown University. Washington, DC. , Pp: 21-27.

Shaheen.A.A, Diaeldin.M, Chaaya.M, El-Roueiheb.Z(2007):Evidence from national studyon women giving birth in 1999, Eastern Mediterranean Health Journal 13(6):1392-404.

Sriprasert I, Chaovisitsaree S, Sribanditmongkhol N, Sunthornlimsiri $N$, Kietpeerakool C92014): Unintended pregnancy and associated risk factors among young pregnant women. Int $\mathrm{J}$ Gynecol Obstet. 2014;128(3):228-31. doi: 10.1016/j.ijgo.2014.09.004.

Stephenson R, Koenig MA, Acharya R, Roy TK(2008): Domestic violence, contraceptive use, and unwanted pregnancy in rural India. Studies in Family Planning ; 39(3):177-186.

World Health Organization (2013): Family Planning, viewed on 11 March 3013, from http://www.who.int/mediacentre/factsheets/fs351/en/index.html.

WHO (2013): Why do so many women still die in pregnancy or childbirth?, Viewed on 11 march, from http://www.who.int/features/qa/12/en/index.html. 


\section{معدل انتشار الحمل غير المقصود و الأسباب المتعلقة به في مدينة بورسعيد}

أ.د / سناءعلي نور-أ.م.د/ هديات عبد الرؤوف عماشةـ أ.م.د/نجاة صلاح سلامة ـ م.م/ شيماء عبد الرحمن عثمان عبد الحليم

أستاذ تصريض النساء والتولبي ـ كلبة التهريض ـ جامعة الزقازيق ـ أستاذ مساعد مدرس تمريض الأمومة و النساء و التوليد ـ كلية التصريض - جامعة بورسعيد ـ أستاذ مساعد مدرس تمريض الأمومة و النساء و التوليد كلبة التمريض - جامعة بورسعيد - مدرس مساعد تصريض الأمومة و النساء والتوليب - كلية التصريض- جامعة بورسعيد

\section{الـخـلاصـــة}

الحمل غير المقصود هو مشكلة صحية عامة مهمة في كلا من البلدان أصحاب الدخل المرتفع و أيضا في البلدان متوسطه أو منخفضة الدخل نتيجة لارتباطها السلبي مع النتائج الاجتماعية والصحية لكل من الأمهات والأطفال .تهدف هذه الدراسة إلي معرفة معدل انتشار و محددات الحمل غير المقصود في مدينة بورسعيد. أجريت هذه الدراسة في عيادات ما قبل الولادة في جميع المر اكز الصحية و العيادات الخارجية بالمستشفيات في مدينة بورسعيد. تم استخدام أداة اعتمادا على المر اجع التمريضية الحديثة حيث تم استخدام در اسة وصفية مقطعية

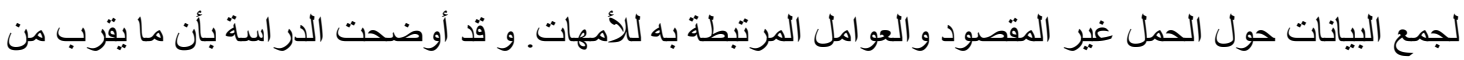
ثلث النساء تعرضن إلى الحمل غير المقصود. وخلصت الدراسة إلى أهمية تفعيل حملات عن تنظيم الأسرة بثكل

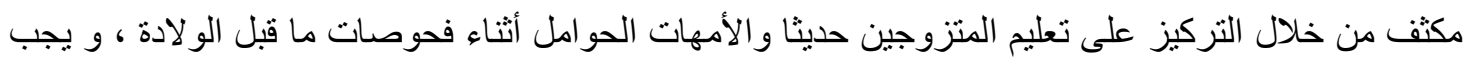
تحديد النساء من ذوي الاحتياجات و توفير سهولة الوصول من وسائل منع الحمل و المعلومات المتعلقة باستخدام وسائل منع الحمل لهم. وبهذه الطريقة تقل نسبة وفيات الرضع و الأمهات وكذللك انخفاض الحاجة إلى الإجهاض و

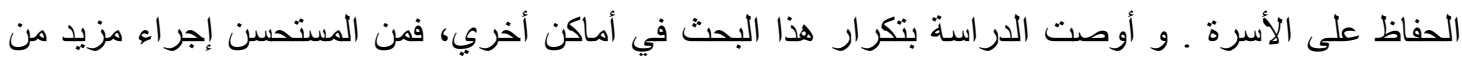

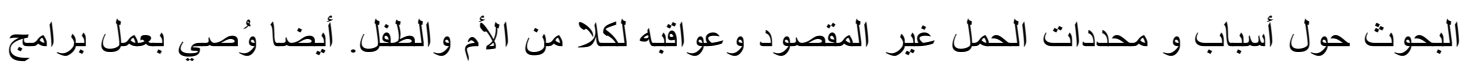

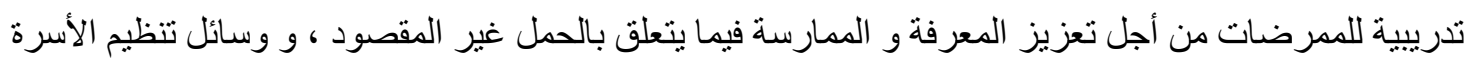

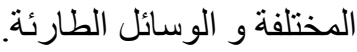

